\title{
Slope Gradient and Vegetation Cover Effects on The Runoff and Sediment Yield in Hillslope Agriculture
}

\author{
Obaid ur Rehman ${ }^{1}$, Muhammad Rashid ${ }^{1 *}$, Rahina Kausar ${ }^{1}$, Sarosh Alvi $^{2}$, Riaz Hussain ${ }^{3}$ \\ ${ }^{1}$ Soil and Water Conservation Research Station, Fateh Jang, Pakistan \\ ${ }^{2}$ Soil Fertility Survey and Soil Testing Institute, Rawalpindi, Pakistan \\ ${ }^{3}$ Soil and Water Conservation Research Institute, Chakwal, Pakistan
}

A R T I C L E I N F O

Article history:

Received 10 December 2014

Accepted 11 February 2015

Available online, ISSN: 2148-127X

Keywords:

Sloppy lands

Sediment loss

Water loss

Slope gradients

Cover crops

Pakistan

${ }^{*}$ Corresponding Author:

E-mail: rashid_hameedi@hotmail.com
A B S T R A C T

Cultivation of field crops is a challenge and risky business in sloping areas. A study was conducted as a demonstration model for the sloppy lands of Fateh Jang, Pakistan. The objectives of this study were to monitor the runoff water and soil sediment loss under different vegetative covers and slope gradients in comparison with bare fallow on each slope gradient. Three artificial slope gradients i.e., $1 \%, 5 \%$ and $10 \%$ were established and three crops i.e., Wheat, Gram and Lentil were cultivated on each slope gradient. Soil and water losses were quantified against each slope gradient and every cover crop for the period of 4 years. Total soil sediment losses during this study were $51 \%$ in Lentil, $30 \%$ in Gram and $25 \%$ in Wheat were lesser compared with bare soil whereas, water losses from Lentil, Gram and Wheat were $69 \%, 75 \%$ and $73 \%$ lesser respectively while compared with bare plots. The highest soil and water losses were monitored at $10 \%$ slope gradient following $5 \%$ and then $1 \%$ slope gradients respectively.

\section{Introduction}

Soil erosion by water is the result of interplay between catchment environmental factors such as soil topography, drainage, rainfall, and land use pattern. The concurrence of drought, water shortage and soil and water loss is the greatest limiting factor for socially and economically sustainable development in arid-semiarid regions of Pakistan. These soil losses are continually leading to critical degradation of soil characteristics, decreased soil productivity and crop production, causing agroecological, environmental and watershed-function problems (Panomtaranichagul and Nareuban, 2005). Therefore more effective soil and water conservation measures are essential for sustainable increases in productivity on cultivated highland slopes. Knowledge of the volume and rates of runoff generated in response to rainfall is very important. Rainfall is purely a natural phenomenon almost beyond the scope of human intervention until now, whereas runoff is largely the product of the interaction of rainfall with many factors over the land surface. Runoff is generated in a number of ways. Slope runoff is not only the greatest source of soil and water loss, but also important water for crop production. Erosion is expected to increase with increase in slope steepness and slope length could be a result of respective increase in velocity and volume of surface runoff. Vliet et al. (1995) reported a significant effect of slope on soil and runoff losses.

Soil erosion from agricultural practices is one of the most serious problems in mountainous areas where there are frequent heavy rains. Soil loss on slopes covered with vegetation is very little. However, with removal of the vegetation, surface soil can easily erode and if cultivated, erosion becomes even more serious. Therefore, when lands on slopes are cleared for cultivation, unless measures to stop soil erosion are taken, fertile surface soils may erode with heavy rain and the land becomes barren within only a few years (Itani, 1998). Protection of soil by means of the vegetation cover is the basic principle of fight against water erosion (Gordon et. al. 2008; Uhlirova and Podhrazska, 2007; Saco et al., 2007) and it also enhances water infiltration rate (Hejduk and Kasprzak 2004, 2005). Vegetative cover can cause a decrease in the frequency of the surface runoff and a small variation in vegetative cover can drastically affect the surface runoff (Wei et al., 2011). Hofman et al. (1985) also described that vegetation cover was a dominant factor in controlling the surface runoff and water erosion from agricultural lands. Nutrient loss is an important 
aspect of surface erosion, since nutrients are concentrated in the surface layers. Runoff is related to the vegetation pattern on the slopes. The vegetation distribution on the slopes is not only conditioning the hydrological processes, but also the sediment movement across and along slopes. In this way vegetation maximizes runoff harvest and the resistance to sediment movement (Bregas et al., 1999).

Soil erosion and water loss hazards in rainfed areas are very severe. It has been reported that $76 \%$ of the total area of Pakistanis subjected to erosion in one form or the other. Out of which water erosion is active on $36 \%$ and wind erosion on $40 \%$ area (Rafiq, 1984). Research findings on the relationship between soil loss and productivity indicate that erosion causes considerable deterioration in soil fertility and crop yields (National Soil Erosion-Soil Productivity Research Planning Committee, 1981). In Pakistan, rainfed region have an uneven topography and is directly or indirectly dependent on rainfall. Almost $60-70$ percent rainfall occurs in months of June to August. The areas receiving rainfall less than $500 \mathrm{~mm}$ are not suited to continuous cropping due to shortage of water supply. This tract has lot of potential for raising crops which can significantly play an important role in the economy of the country. The main soil problems of rainfed area include soil erosion, loss of soil water and low soil fertility due to uneven sloping topography. Knowledge of rainfall-runoff and runoff-soil loss relationship in these areas is very important to develop appropriate technology for soil and water conservation for increased crop production. In these relationships not only the amount of rainfall is important, but also its intensity. Erratic and torrential rainfalls are more damaging than gentle uniform rains. The other factor affecting these relationships is surface cover and gradient (Ahmad et al., 1984). Keeping in view the long term sustainability and productivity of eroded lands, the present research was carried out to study the effect of slope steepness and different cover crops on soil and water and on crop yields.

\section{Materials and Methods}

\section{Site and Experiment}

The study was initiated at Soil and Water Conservation Research Station (SAWCRS), Fateh Jang (latitude $33.55^{\circ} \mathrm{N}$, longitude $72.58^{\circ} \mathrm{E}$ and $402 \mathrm{~m}$ high from the sea level), from 2007-11 to monitor the soil and water losses at different topography under most commonly cropping patterns of the rainfed region. Keeping in view the undulating topographic features of the lands of this particular tract, artificial slope gradients $(1 \%, 5 \%$ and $10 \%)$ were established. Three plots of each slope gradient were constructed. Each plot was $5 \mathrm{~m}$ long and $2 \mathrm{~m}$ wide which constitutes an area of $10 \mathrm{~m}^{2}$. Every plot was connected to a $200 \mathrm{~L}$ plastic tank through a $5^{\prime}$ dia plastic pipe. The boundaries of each plot were raised through bricks to collect all run off in this tank. Runoffs were measured all the year round. Recorded data about amounts of water were converted to cubic meters per hectare $\left(\mathrm{m}^{3} \mathrm{ha}^{-1}\right)$. Data about amounts of washed-out soil related to the measuring unit of tons per hectare $\left(\mathrm{t} \mathrm{ha}^{-1}\right)$ in a similar manner. The run off data was analyzed for every rainfall event $\geq 20 \mathrm{~mm}$. The winter crops (Wheat, Gram and Lentil) were grown on the slope plots in the respective growing season. Before sowing of crops recommended rates of fertilizer nutrients (Wheat NPK @ 46, 34, 25; Gram NPK @ 12,37,0 and Lentil NPK @ 12, $23,0 \mathrm{Kg} \mathrm{acre}{ }^{-1}$ ) were added into the soil in the form of Urea, DAP and SOP. One plot of each slope gradient was kept fallow as a check (bare soil).

\section{Climate and Soil}

The climate is arid with an average annual temperature of $22.2^{\circ} \mathrm{C}$. The monthly mean temperature ranges from about $11^{\circ} \mathrm{C}$ in January to $31^{\circ} \mathrm{C}$ in June. The total annual precipitation is $988 \mathrm{~mm}$ and 70 percent rainfall falls in between June to August. The most common soil types have silt $20-40 \%$ and clay varying from $18-23 \%$. The soil has less resistance to the erosion (Ullah et al., 2009).

\section{Data Collection on Soil Loss and Runoff}

After each rainstorm $\geq 20 \mathrm{~mm}$, for the determination of the amount of soil and water loss per rainfall event, the depth of runoff in each container was measured to calculate runoff volume and $1 \mathrm{~L}$ of runoff water was sampled from each container after stirring and mixing. After being filtered, the remaining sediment was dried at low temperature $\left(45^{\circ} \mathrm{C}\right.$ for $12 \mathrm{~h}$ drying) to measure sediment concentration. Then, the dried sediment samples were transported to the SAWCRS for laboratory analysis. Depth of water in plastic tank was measured to calculate total amount of water loss per rain storm. Then, from this data accumulative soil and water loss per cropping period was noted every year from each plot of all slope gradients (Tegenu, 2009).

\section{Crop Yield Determination}

One $\mathrm{m}^{2}$ of crop plants were sampled from all the plots of each slope gradients for grain yield assessment under different slope gradients.

\section{Rainfall}

Rainfall (mm) was recorded at study site (Fig. 1).

\section{Statistical Analysis}

The data collected was statistically analyzed using the methods described by Steel and Torrie (1997). MS Word \& Excel-2010 and M-Stat C computer softwares were used to compare the differences.

\section{Results and Discussion}

Soil Loss under Different Slope Gradients

Slope gradient is one of the important factors that affect the soil loss in sloppy lands. The runoff and soil loss intensity can vary with different slope gradients. Total soil loss through runoff by rainfall events from 2008-09 to 2011-12 (Rabi Period) is listed in Table 2 which shows that runoff mostly occurs in February and March during Rabi season, and it is in accordance with rainfall distribution from 2008-09 to 2011-12 (Fig1). The maximum average soil loss $\left(0.2432 \mathrm{t} \mathrm{ha}^{-1}\right)$ had taken place at $10 \%$ slope gradient in control (bare soil) while the 
minimum soil sediment loss $\left(0.0416 \mathrm{tha}^{-1}\right)$ was quantified in $1 \%$ slope gradient under gram cover. Comparison of soil loss between different plots under different vegetation covers indicated that with increasing slope gradient amount of soil loss increased significantly since the slope gradient is the main factor for controlling soil erosion (Koulouri and Giourga, 2007; Yong and Bao, 2012). Several authors have confirmed the exponential influence of slope gradient on soil loss (Roose, 1975, 1977; Lal, 1976). Furthermore, it was noticed that amount and distribution of rainfall was another factor which determined the soil sediment loss. Soil detachment in the form of sediment load was increased with amount (Fig. 1) and distribution of rainfall (Table 2). Vegetation distribution strongly influences the pattern and extent of water and sediment loss (Puigdefábregas, 2005) and rainfall intensity magnified runoff and soil loss (Pelayo et al., 2010). As far as, crop covers are concerned, Gram provided the maximum resistance against the soil erosion followed by Lentil. Where as, Wheat, provided the least protection against soil sediment loss. There are several soil erosion control strategies including vegetation cover to improve sustainable crop productions on a sloping land. According to theory, with increasing shrub vegetation, protection of soil resources is also increased and soil erosion is decreased (Alias et al., 1997) as greater soil loss was occurred without vegetation cover. Panomtaranichagul and Nareuban (2005) studied that erosion rate markedly decreased after root development and protected by the increased crop canopy during rainy season. The results obtained agree with those observed by different authors in different environments, who consider that runoff and sediment yield decrease with an increase in soil cover with vegetation (Bochet et. al., 1998; Durán et. al., 2006; Roxo, 1994). Thornes (1988) suggests that a value of $40 \%$ vegetation cover is considered critical, below which accelerated erosion dominates on sloping lands. If the vegetation cover covers an area of more than $40 \%$, it will act as a protective factor for the land. The lower rainfall in semiarid areas compared to that in humid climates does not necessarily result in a corresponding low level of soil erosion by water. This is mainly due to the torrential and erratic nature of the rains (FAO, 1987).

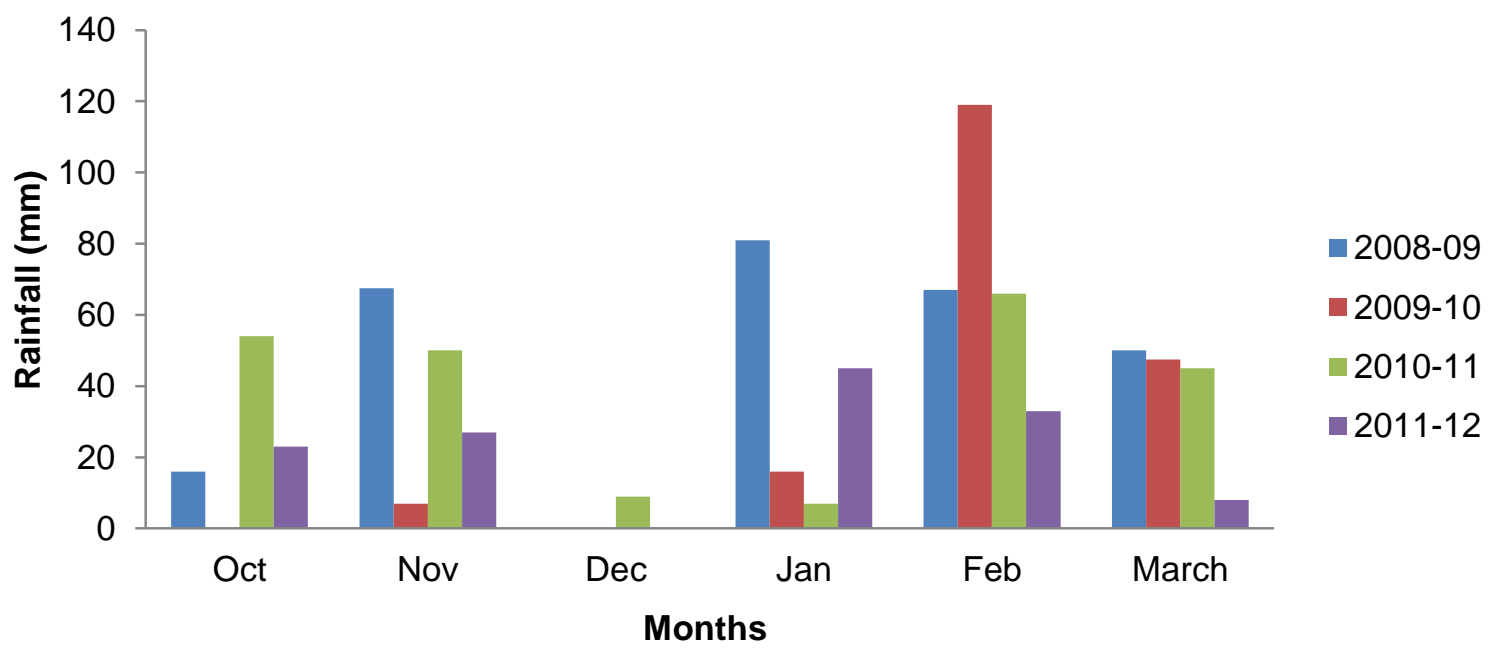

Fig. 1 Rainfall at Study Site (Winter Season)

Table 1 Effect of Slope Gradients and Cover Crops on Soil Loss (t ha-1) With Rainfall

\begin{tabular}{c|ccccccc}
\hline $\mathrm{R}^{*} \geq 20 \mathrm{~mm}$ & Cover Crop & Slope Gradient (\%) & $2008-2009$ & $2009-2010$ & $2010-2011$ & $2011-2012$ & Mean \\
\hline \multirow{3}{*}{4} & \multirow{3}{*}{ Fallow } & 1 & 0.1823 & 0.1121 & 0.1321 & 0.0618 & 0.1221 \\
& & 5 & 0.2442 & 0.1422 & 0.1598 & 0.0961 & 0.1606 \\
& & 10 & 0.424 & 0.1876 & 0.2289 & 0.1321 & 0.2432 \\
3 & \multirow{3}{*}{ Wheat } & 1 & 0.1114 & 0.0926 & 0.1021 & 0.0411 & 0.0868 \\
& & 5 & 0.166 & 0.1156 & 0.1398 & 0.0769 & 0.1246 \\
2 & \multirow{3}{*}{ Gram } & 10 & 0.3285 & 0.1392 & 0.1583 & 0.1002 & 0.1816 \\
& & 1 & 0.0541 & 0.0501 & 0.0522 & 0.0101 & 0.0416 \\
& & 5 & 0.2198 & 0.1365 & 0.1891 & 0.0365 & 0.1455 \\
3 & \multirow{3}{*}{3} & 10 & 0.2827 & 0.169 & 0.2081 & 0.06 & 0.1800 \\
& Lentil & 1 & 0.0644 & 0.0611 & 0.0671 & 0.0566 & 0.0623 \\
& & 5 & 0.0887 & 0.0723 & 0.0862 & 0.0681 & 0.0788 \\
\hline
\end{tabular}


Water Loss under Different Slope Gradients

Runoff production on slopes is a result of water flow along the earth's surface, as well as rainfall entering the soil. Rainfall infiltrates the soil and runoff commences when rainfall intensity exceeds infiltration capacity. Planting different crops in the study area at different slope gradients, changes the runoff. Data of runoff is presented in Table 2 showed a significant difference under different slope gradients and crop covers. Following the bare soil $\left(376.79 \mathrm{~m}^{3} \mathrm{ha}^{-1}\right)$ the runoff was the maximum by planting wheat $\left(126.14 \mathrm{~m}^{3} \mathrm{ha}^{-1}\right)$, followed by gram $\left(112.85 \mathrm{~m}^{3} \mathrm{ha}\right.$ $\left.{ }^{1}\right)$, and were the least with lentil (105.79 $\left.\mathrm{m}^{3} \mathrm{ha}^{-1}\right)$, approximately. Slope gradient is one of the important factors that affect soil erosion in the same rainfall conditions. The over land flow and soil erosion intensity are different due to varying slope gradients. The trend of water loss change with the increase of gradient is same among three crops. A close relationship was found between sediment load and runoff like the sediment loss. The highest amount of water loss was occurred at $10 \%$ slope gradient $>5 \%$ slope gradient $>1 \%$ slope gradient. Runoff is that part of rainfall which moves down-slope towards stream channels undergoing interaction with soil infiltration, surface detention, soil moisture storage, evapotranspiration, interception by vegetation, steepness of land slope, nature and type of parent material. Relief features, hydrological cycle, vegetative cover pattern, surface features due to micro-depression or even surface roughness, watershed morphology and the underground water storing capacity would have obvious contribution to the degree and magnitude of runoff. Almas and Jamal (1999); Khan and Bhatti (2000) demonstrated that maintenance of adequate surface cover, may serve to conserve soil and water resources. It was observed that only a few months of rainfall in each year contributed most of the rainfall. It can be seen that the quantity of water loss was not only influenced by the crop type and cover, but also by slope steepness. Generally, plots with steeper up slope had greater soil loss than those with lower arrangements of slope steepness (Table 2 and 3). Negative exponential relationship between plant cover and runoff was found (Gimeno-García et al., 2007). The vegetation plays a very significant role in controlling runoff generation and erosion (Calvo et al., 2003). Rainfall is erratic with varying intensity, duration, frequency and distribution, whereas runoff is that part of rainfall. Land slope and rainfall occurrence time contribute to runoff variably. High rainfall intensity could lead to in increase runoff amount (Songwel et al., 2007). Two aspects promote the capacity of vegetation in controlling water runoff and soil loss. On the one hand, vegetation could improve soil texture and hydrologic properties by root growth activity and on the other hand, canopy cover intercepts rainfall and litter decrease runoff energy (Xu et al., 2006). Similar to the study by Bochet et al. (2006), this study also found that different species had varied effectiveness against runoff control.

Table 2 Effect of Slope Gradients and Cover Crops on Water Loss (m3 ha-1) With Rainfall

\begin{tabular}{c|ccrrrrr}
\hline $\mathrm{R}^{*} \geq 20 \mathrm{~mm}$ & Cover Crop & Slope Gradient (\%) & $2008-2009$ & $2009-2010$ & $2010-2011$ & $2011-2012$ & Mean \\
\hline \multirow{3}{*}{4} & \multirow{3}{*}{ Fallow } & 1 & 293.35 & 210.35 & 280.25 & 200.21 & 246.04 \\
& & 5 & 347.72 & 290.72 & 340.15 & 264.44 & 310.76 \\
& & 10 & 472.04 & 326.04 & 398.25 & 310.84 & 376.79 \\
3 & \multirow{3}{*}{ Wheat } & 1 & 56.60 & 50.60 & 52.50 & 42.30 & 50.50 \\
& & 5 & 84.54 & 70.54 & 76.48 & 61.47 & 73.26 \\
& & 10 & 146.88 & 119.88 & 125.59 & 112.22 & 126.14 \\
2 & \multirow{3}{*}{ Gram } & 1 & 45.23 & 33.23 & 38.12 & 29.06 & 36.41 \\
& & 5 & 101.52 & 78.52 & 98.09 & 56.41 & 83.64 \\
& & 10 & 131.82 & 111.82 & 119.56 & 88.19 & 112.85 \\
3 & \multirow{3}{*}{ Lentil } & 1 & 93.00 & 85.43 & 88.21 & 76.20 & 85.71 \\
& & 5 & 106.11 & 86.58 & 99.15 & 84.80 & 94.16 \\
& & 10 & 128.04 & 97.75 & 108.97 & 88.41 & 105.79 \\
\hline
\end{tabular}

$\mathrm{R}^{*}$ : Rainstorm

Table 3 Effect of slope gradients and cover crops on grain yield ( $\mathrm{Kg}$ ha-1) with rainfall

\begin{tabular}{|c|c|c|c|c|c|c|c|}
\hline $\mathrm{R} * \geq 20 \mathrm{~mm}$ & Cover Crop & Slope Gradient (\%) & 2008-2009 & $2009-2010$ & $2010-2011$ & 2011-2012 & Mean \\
\hline \multirow{3}{*}{4} & \multirow{3}{*}{ Fallow } & 1 & $* *$ & $* *$ & $* *$ & $* *$ & $* *$ \\
\hline & & 5 & $* *$ & $* *$ & $* *$ & $* *$ & $* *$ \\
\hline & & 10 & $* *$ & $* *$ & $* *$ & $* *$ & $* *$ \\
\hline \multirow{3}{*}{3} & \multirow{3}{*}{ Wheat } & 1 & 4.21 & 3.56 & 3.65 & 1.58 & 3.25 \\
\hline & & 5 & 4.00 & 3.22 & 3.44 & 1.20 & 2.97 \\
\hline & & 10 & 3.56 & 3.19 & 3.31 & 1.04 & 2.78 \\
\hline \multirow{3}{*}{2} & \multirow{3}{*}{ Gram } & 1 & 2.08 & 1.35 & 1.48 & 1.35 & 1.57 \\
\hline & & 5 & 1.74 & 1.25 & 1.66 & 1.14 & 1.45 \\
\hline & & 10 & 1.25 & 1.05 & 1.15 & 0.86 & 1.08 \\
\hline \multirow{3}{*}{3} & \multirow{3}{*}{ Lentil } & 1 & 2.32 & 1.89 & 2.22 & 0.96 & 1.85 \\
\hline & & 5 & 2.21 & 1.93 & 2.05 & 0.72 & 1.73 \\
\hline & & 10 & 1.96 & 1.70 & 1.84 & 0.60 & 1.53 \\
\hline
\end{tabular}


Table 4 Effect of slope gradients and cover crops on biomass yield (t ha-1) with rainfall

\begin{tabular}{|c|c|c|c|c|c|c|c|}
\hline $\mathrm{R}^{*} \geq 20 \mathrm{~mm}$ & Cover Crop & Slope Gradient (\%) & $2008-2009$ & $2009-2010$ & $2010-2011$ & $2011-2012$ & Mean \\
\hline \multirow{3}{*}{4} & \multirow{3}{*}{ Fallow } & 1 & $* *$ & $* *$ & $* *$ & $* *$ & $* *$ \\
\hline & & 5 & $* *$ & $* *$ & $* *$ & $* *$ & $* *$ \\
\hline & & 10 & $* *$ & $* *$ & $* *$ & $* *$ & $* *$ \\
\hline \multirow{3}{*}{3} & \multirow{3}{*}{ Wheat } & 1 & 11.99 & 6.96 & 7.73 & 6.1 & 8.20 \\
\hline & & 5 & 10.8 & 6.5 & 7.2 & 5.66 & 7.54 \\
\hline & & 10 & 9.7 & 6 & 6.88 & 5.33 & 6.98 \\
\hline \multirow{3}{*}{2} & \multirow{3}{*}{ Gram } & 1 & 7.64 & 7.2 & 7.5 & 7.12 & 7.37 \\
\hline & & 5 & 7.08 & 6.35 & 6.96 & 6.27 & 6.67 \\
\hline & & 10 & 6.15 & 6.22 & 6.4 & 6.1 & 6.22 \\
\hline \multirow{3}{*}{3} & \multirow{3}{*}{ Lentil } & 1 & 6.1 & 4.95 & 5.32 & 4.66 & 5.26 \\
\hline & & 5 & 5.92 & 4.21 & 5.11 & 4.24 & 4.87 \\
\hline & & 10 & 5.79 & 4.12 & 4.54 & 3.96 & 4.60 \\
\hline
\end{tabular}

\section{Crop Grain and Biomass Yields under Different Slope} Gradients

Planting different crops in the study site, changes of the simulation data of yield with different slope gradient. It was observed that different crops' yields vary significantly. With the increase of topographic gradient, the simulation data of five crops' yields show a decreasing trend. The average grain yields of wheat, gram and lentil were $3.25 \mathrm{Kg} \mathrm{ha}^{-1}, 1.57 \mathrm{Kg} \mathrm{ha}^{-1}$ and $1.85 \mathrm{Kg} \mathrm{ha}^{-1}$ on topographic gradient of $1 \%$, respectively, while the grain yields decrease to $2.97 \mathrm{Kg} \mathrm{ha}^{-1}, 1.45 \mathrm{Kg} \mathrm{ha}^{-1}$ and $1.73 \mathrm{Kg} \mathrm{ha}^{-1}$ on slope gradient of $5 \%$, respectively. Similarly grain yields of wheat, gram and lentil were decreased to $2.78 \mathrm{Kg} \mathrm{ha}^{-1}, 1.08 \mathrm{Kg} \mathrm{ha}^{-1}$ and $1.53 \mathrm{Kg} \mathrm{ha}^{-1}$ respectively at $10 \%$ slope gradient. With the increase of topographic gradient, the data of grain yields show a diverse decreasing trend. As a whole, topographic gradient strongly influences crop yield. The yield declines as the gradient rises. Different crops have different sensitivity to the variation of gradients. The canopies of different crops can reduce the erosive power of the raindrops (Sinun et al., 1992), and they provide materials for soil. As a result, the energy of raindrops, which is dependent on the raindrops' size and velocity, is reduced to almost zero when the raindrops reach the soil (Binkley and Brown, 1993). Furthermore, their rooting systems will also hold soil particles effectively and make the soil more resistant to erosion. Penetration by the roots and their subsequent growth can compact the soil in the immediate vicinity (Greacen and Sands, 1980). Other studies confirmed that an increase of vegetative cover results in a significant reduction in discharge and sediment (Niehoff et al., 2002; Wegehenkel, 2002).

\section{Conclusions}

Topographic gradient has an important influence on crop yield, the bigger gradient resulted the lowest crop yield. The suitable crop for Rabi in the slopping land could be is gram, being the most resistant against soil erosion. Wheat is not suitable for planting on large scale on slopping lands because of the poor soil and water conservation benefits. Under the same topographic condition, different crops' runoff and soil loss indicated clear differences.

\section{References}

Ahmad S, Shafiq M, Ikram MA. 1984. Rainfall intensity-runoff relationship for small catchments in Pothwar plateau. J. of Engg. App. Sci., 3: 37-44.

Alias LJ, Lopez-Bermudez F, Marin-Sanleandro P, Romero-Diaz MA, Martinez J. 1997. Clay minerals and soil fertility loss on Peric Calcisol under a semiarid Mediterranean environment. Soil Technol., 10: 9-19.

Almas M, Jamal T. 1990. Nutrients loss through sediment and runoff under upland banana-pineapple intercropping system. Pak. J. Soil Sci., 16: 11-16.

Binkley D, Brown TC. 1993. Management impacts on water quality of forests and rangelands. Gen. Tech. Rep. RM-239. USDA Forest Service, Fort Collins.

Bochet E, Rubio JL, Poesen J. 1998. Relative efficiency of three representative matorral species in reducing water erosion at the microscale in a semi-arid climate (Valencia, Spain).Geomorph., 23:139-150.

Bochet E, Poesen JL, Rubio JL. 2006. Runoff and soil loss under individual plants of a semi-arid Mediterranean shrub-land: influence of plant morphology and rainfall intensity. Earth Surf. Proc. Landforms, 31: 536-549.

Calvo CA, Fayos CB, Imeson JC. 2003. Runoff generation, sediment movement and soil water behaviour on calcareous (limestone) slopes of some Mediterranean environments in southeast Spain. Geomorph., 50: 269-291.

Duran Z, Martínez JRF, Pleguezuelo CRR, Raya M, Rodríguez BC. 2006. Soil-erosion and runoff prevention by plant covers in a mountainous area (SE Spain): implications for sustainable agriculture. Earth and Environ. Sci., 26(4): 309-319.

FAO.1987. Soil and water conservation in semiarid areas. Soils Bulletinno.57, FAO, Rome, Italy.

Gimeno-Garcia E, Andreu V, Rubio JL. 2007. Influence of vegetation recovery on water erosion at short and medium-term after experimental fires in a Mediterranean shrub-land. Catena 69: $150-160$.

Pelayo G, Andreu V, Gimeno-García E, Campo J, Rubio JL. 2010. Rainfall influence on plot-scale runoff and soil loss from repeated burning in a Mediterranean-shrub ecosystem, Valencia, Spain. Geomorph., 118: 444-452.

Gordon JM, Bennett SJ, Alfonso CV, Bingner RL. 2008. Modeling long term soil losses on agricultural fields due to ephemeral gully erosion. J. Soil and Water Cons., 63: 173-181.

Greacen EL, Sands R. 1980. Compaction of forest soils: a review. Aus. J. Soil Res., 18: 163-189.

Hejduk S, Kasprzak K. 2005. A contribution to proposals of the width of protective grasslands strips. Soil and Water, 4: 30-35.

Hejduk S., Kasprzak K. 2004. Advantages and risks of grassland stand from the viewpoint of flood occurrence. Grassland Sci. in Eur., 9: 228-230. 
Heluf G, Mishra BB, Kibret B. 2006. Missing linkage in rainfallrunoff-soil water relationship for sustainable watershed development: A case study around Hirna, Eastern Ethiopia. J. Food, Agri. Environ., 4(1): 239-245.

Hofman I, Ries RF, Gilley GE. 1985. Relationship of Runoff and Soil Loss to Ground Cover of Native and reclaimed grazing land. Agron. J., 75: 599-607.

Itani J. 1998. Evaluation of an indigenous farming system in the Matengo Highlands, Tanzania, and its sustainability. African Study Monographs, 19: 55-68.

Khan F, Bhatti AU. 2000. Soil and nutrient losses through sediment under wheat mono-cropping and barley-legume inter-cropping from up-land sloping soil. Pak. J. Soil Sci., 18: 45-50.

Koulouri M, Giourga C. 2007. Land abandonment and slope gradient as key factors of soil erosion in Mediterranean terraced lands. J. Catena, 69: 274-281.

Lal R. 1976. Soil erosion problems on an Alfisol in Western Nigeria, and their control. Monograph No. 1, IITA, Ibadan, Nigeria.

Mariano MH, José M, Nicolau, Martín LM, Bradford PW. 2010. Plot-scale effects on runoff and erosion along a slope degradation gradient. Water Resour. Res., 46: 4503.

National Soil Erosion-Soil Productivity Research Planning Committee. 1981. Soil erosion effects on soil productivity: A research perspective. J. Soil and Water Cons., 36: 82-90.

Niehoff D, Fritsch U, Bronstert A. 2002. Land-use impacts on storm-runoff generation: scenarios of land-use change and simulation of hydrological response in a meso-scale catchment in SW-Germany. J. Hydrol., 267: 80-93.

Panomtaranichagul M, Nareuban S. 2005. Improvement of Water Harvesting and Anti-Erosive Cultural Practices for Sustainable Rainfed Multiple Crop Production on Sloping Land. Conference on International Agricultural Research for Development. Stuttgart-Hohenheim, October 11-13, 2005.

Bregas FJ. 2005. The role of vegetation patterns in structuring runoff and sediment fluxes in drylands. Earth Surf. Processes Land-forms, 30: 133-147.

Puigdefabregas J, Sole A, Gutierrez L, Del Barrio L, Boer M. 1999. Scales and processes of water and sediment redistribution in drylands: results from the Rambla Honda field site in South-east Spain. Earth-Sci. Reviews, 48: 39-70.

Rafiq M. 1984. Presentation report of operational watershed management Project, Pakistan Agricultural Research Council, Islamabad, Pakistan.

Roose EJ. 1975. Erosion et ruissellement en Afrique de l'Ouest. Vingt Annees de Mesures en Petites Parcelles Experimentales. "' Abidjan. ORSTOM.
Roose EJ. 1977. Use of the Universal Soil Loss Equation to predict erosion in West Africa. In: Foster, G.R. Ed. Soil Erosion: Prediction and Control. Spec. Publ. No. 21, Soil Conserv. Soc. Am., Ankeny, IA, pp. 60-74.

Roxo MJ. 1994. A acção antrópica no processo de degradação de solos - a Serra de Serpa e Mértola. PhD, Portugal: Universidade Nova de Lisboa.

Saco PM, Willgoose GR, Hancock GR. 2007). Eco-geomorphology of banded vegetation patterns in arid and semi-arid regions. Hydrol. Earth Syst. Sci., 11: 1717-1730.

Sinun W, Meng WW, Douglas I, Spencer T. 1992. Throughfall, stem-flow, overland flow and through flow in the Ulu Segama rain forest, Sabah, Malaysia. Philosoph. Transact. Royal Soc., 335: 389-395.

Songwel J, Xiubin H, Fangqiang W. 2007. Soil organic carbon loss under Hilly Region. Wuhan University J. of Natural Sci., 12: 695-698.

Tegenu AE. 2009. Modeling rainfall, runoff and soil loss relationships in the northeastern highlands of Ethiopia. Andit Tid Watershed. M. Sc. Thesis. Faculty of the Graduate School of Cornell University.

Thornes JB. 1988. Erosional equilibria under grazing. In J. Bintliff, D. Davidson, \& E. Grant (Eds.), Conceptual issues in environmental archaeology.193-210. Edinburgh University Press.

Uhlírová J, Podhrázská J. 2007. Evaluation of efficiency of the flood and erosion protecting measure-ments. Pozemkové úpravy, 61: 10-12.

Ullah R, Lone MI, Ali S, Hussain S. 2009. Soil water variation under different cropping patterns on sloppy lands in Punjab, Pakistan Soil \& Environ., 28: 156-161.

Vliet VLJ.P, Hall JW, Vliet VLJP. 1995. Effects of planting direction of Brussels sprouts a previous cultivation on water erosion in southwestern British Columbia, Canada. J. Soil and Water Cons., 50: 188-192.

Wegehenkel M. 2002. Estimating of impact of land use changes using the conceptual hydrological model THESEUS - a case study. Physics and Chem. of the Earth, 27: 631-640

Wei M, Bogaard TA, Beek R. 2011. Dynamic effects of vegetation on the long-term stability of slopes: components of evaporation. Geophysical Res. Abstracts., 13: 7720-7725.

Xu X, Zhang K, Kong Y, Chen J, Yu B. 2006. Effectiveness of erosion control measures along the Qinghai-Tibet plateau highway, Tibetan plateau, China. Transportation Research, Part D: Transport and Environ., 11:302-309.

Yong Y, Bao STX. 2012. Effects of slope gradient on slope runoff and sediment yield under different single rainfall conditions. 23:1263-1268. 